\title{
Undergraduate courses for enhancing design ability in naval architecture
}

\author{
Kyu-Yeul Lee ${ }^{1}$, Namkug $\mathrm{Ku}^{2}$ and Ju-Hwan $\mathrm{Cha}^{3}$ \\ ${ }^{1}$ Department of the Naval Architecture and Ocean Engineering, and \\ Research Institute of Marine Systems Engineering, Seoul National University, Seoul, Korea \\ ${ }^{2}$ Department of the Naval Architecture and Ocean Engineering, and \\ Engineering Research Institute, Seoul National University, Seoul, Korea \\ ${ }^{3}$ Department of Ocean Engineering, Mokpo National University, Jeollanam-do, Korea
}

\begin{abstract}
Contemporary lectures in undergraduate engineering courses typically focus on teaching major technical knowledge-based theories in a limited time. Therefore, most lectures do not allow the students to gain understanding of how the theories are applied, especially in Naval Architecture and Ocean Engineering departments. Shipyards require students to acquire practical ship design skills in undergraduate courses. To meet this requirement, two lectures are organized by the authors; namely, "Planning Procedure of Naval Architecture \& Ocean Engineering” (PNAOE) and "Innovative Ship Design” (ISD). The concept of project-based and collaborative learning is applied in these two lectures. In the PNAOE lecture, sophomores receive instruction in the designing and building of model ships, and the students' work is evaluated in a model ship contest. This curriculum enables students to understand the concepts of ship design and production. In the ISD lecture, seniors learn how to develop their creative ideas about ship design and communicate with members of group. They are encouraged to cooperate with others and understand the ship design process. In the capstone design course, students receive guidance to facilitate understanding of how the knowledge from their sophomore or junior classes, such as fluid mechanics, statics, and dynamics, can be applied to practical ship design. Students are also encouraged to compete in the ship design contest organized by the Society of Naval Architects of Korea. Moreover, the effectiveness of project-based and collaborative learning for enhancing interest in the shipbuilding Industry and understanding the ship design process is demonstrated by citing the PNAOE and ISD lectures as examples.
\end{abstract}

KEY WORDS: Capstone design; Naval architecture; Design ability; Project-based learning; Collaborative learning.

\section{INTRODUCTION}

The conventional undergraduate engineering curriculum is based on classroom lectures and mainly focused on teaching theories and technical knowledge. However, this curriculum does not enable students to develop design abilities they need to keep up with the rapid progress in engineering. Especially in the field of naval architecture, the huge scale of ships and offshore structures, which are the main products of naval architecture, make it difficult for students to understand the relationship between theory and engineering design. Therefore, two courses were organized by the authors specifically for undergraduates; namely, "PNAOE" and "ISD". PNAOE is a lecture that aims to enhance sophomores' interest in naval architecture. ISD, on the other hand, is a capstone design course for seniors.

Corresponding author: Namkug Ku

e-mail:knk80@snu.ac.kr 


\section{Related works}

Project-based learning is where students are assigned a project to execute and take the initiative to solve project-related problems. It is very effective for developing students' practical design ability (Hanai et al., 2007; Ito et al., 2007; Matsuzawa and Ohiwa, 2007).

Besides project-based learning, collaborative learning is also an important and effective learning method. Terenzini et al. (2001) examined the students of undergraduate engineering courses, who are taught using collaborative learning methods, and found they differed from traditional lecture and discussion courses in their ability to promote the development of engineering design, problem-solving, communication, and group participation skills. Moreover, according to Gokhale (1995) and Goodsell et al. (1992), collaborative learning increases participants' interest, promotes critical thinking through the active exchange of ideas in small groups, and can help students develop the sense of community. Shared learning also gives students an opportunity to engage in discussion and it makes them to achieve at higher levels of thought and retain information longer than students who work quietly as individuals (Johnson and Johnson, 1986; Totten et al., 1991).

Because of these merits of project-based and collaborative learning, the students of two lectures (i.e., PNAOE and ISD) are required to form small groups to complete term projects. This paper presents the objectives, contents, characteristics, and learning outcomes of the two courses. This paper is based on the author's textbooks (Lee et al., 2011) and lecture notes (Lee, 2006; Lee, 2009).

\section{COURSE FOR ENHANCING THE INTEREST IN NAVAL ARCHITECTURE: PLANNING PROCEDURE OF NAVAL ARCHITECTURE \& OCEAN ENGINEERING}

In this course, students are encouraged to (1) increase their interests in naval architecture and (2) learn how to apply their knowledge in ship designing. This lecture is comprised of "Designing a Model Ship," and "Constructing a Model Ship."

\section{Designing a model ship}

This is a sophomore course (PNAOE) in which students build a model ship in 15 weeks as a term project, and a model ship contest is held to evaluate the achievement of the students. Students design and build a model ship in accordance with the given subjects. The contest evaluates the speed and maneuverability of each model ship. We use the term "project" to encourage students' interest in naval architecture by learning the relationship between practical ship designing and theory.

\section{Determining the main dimensions of a ship}

In this course, students learn what the main dimensions are and how to determine them. The main dimensions, such as length (L), breadth (B), depth (D), draft (T) and block coefficient (CB), have to satisfy certain design criteria, such as physical, economic, and regulatory constraints. Among these constraints, physical constraint is the most important because they are related to floatability of a ship. The basic theories that the students learn for determining a ship's main dimensions are as follows.

\section{- Hydrostatic equilibrium}

For a ship to float, its total weight must be equal to the buoyancy force exerted on the immersed body.

\section{- Archimedes' principle}

The buoyancy force exerted on an immersed body has the same magnitude as the weight of the fluid displaced by the immersed body.

- Total weight of a ship

The weight of a commercial ship is usually comprised of the lightweight and the deadweight. According to the definition of these weights, the physical constraint, the so-called weight equation, is described as follows: 


$$
\mathbf{F}_{\text {Buoyant }}=\mathbf{W}_{\text {displacement }}=\mathbf{W}_{\text {total }}
$$

where $\mathbf{F}_{\text {Buoyant }}$ is the force exerted on a ship, $\mathbf{W}_{\text {displacement }}$ is the weight of the fluid displaced by the immersed body, and $\mathbf{W}_{\text {total }}$ is a ship's total weight.

$$
\mathbf{W}_{\text {total }}=\mathrm{LWT}+\mathrm{DWT}
$$

where LWT is lightweight and DWT is deadweight, we get the following equation.

$$
\mathbf{W}_{\text {displacement }}=\mathrm{LWT}+\mathrm{DWT}
$$

At this point, displacement can be represented in terms of the main dimensions. The deadweight is given by the owner's requirement. Therefore, the lightweight should be estimated using the appropriate assumption. Because a ship consists of the hull structure, outfit, and machinery, the lightweight can also be estimated as follows.

$$
\mathrm{LWT}=\mathrm{W}_{\mathrm{s}}+\mathrm{W}_{\mathrm{m}}+\mathrm{W}_{\mathrm{o}}
$$

where $\mathrm{W}_{\mathrm{s}}$ is steel weight, $\mathrm{W}_{\mathrm{m}}$ is machinery weight, and $\mathrm{W}_{\mathrm{o}}$ is outfit weight. $\mathrm{W}_{\mathrm{s}}, \mathrm{W}_{\mathrm{m}}$, and $\mathrm{W}_{\mathrm{o}}$ can be assumed to depend on the main dimensions and can be estimated by the weight of the basis ship. The physical constraint is used to roughly determine the main dimensions. After hull form variation, the main dimensions are precisely determined.

\section{Hull form design, compartment design, and structural design using software}

To help students determine the main dimensions and design the hull form, compartment, and structure of a ship, software such as EzOptimizer, EzHULL, EzCOMPART, and EzSTRUCT are provided. The software has been jointly developed by the author's laboratory (Advanced Ship Design Automation Laboratory, Department of Naval Architecture and Ocean Engineering, Seoul National University) and EzGRAPH Co., Ltd. Students learn in the lectures how to use the software. The procedures of ship design using the software are as follows.

- First, students design the hull form of the model ship using the commercial software "EzHULL" (see Fig. 1).

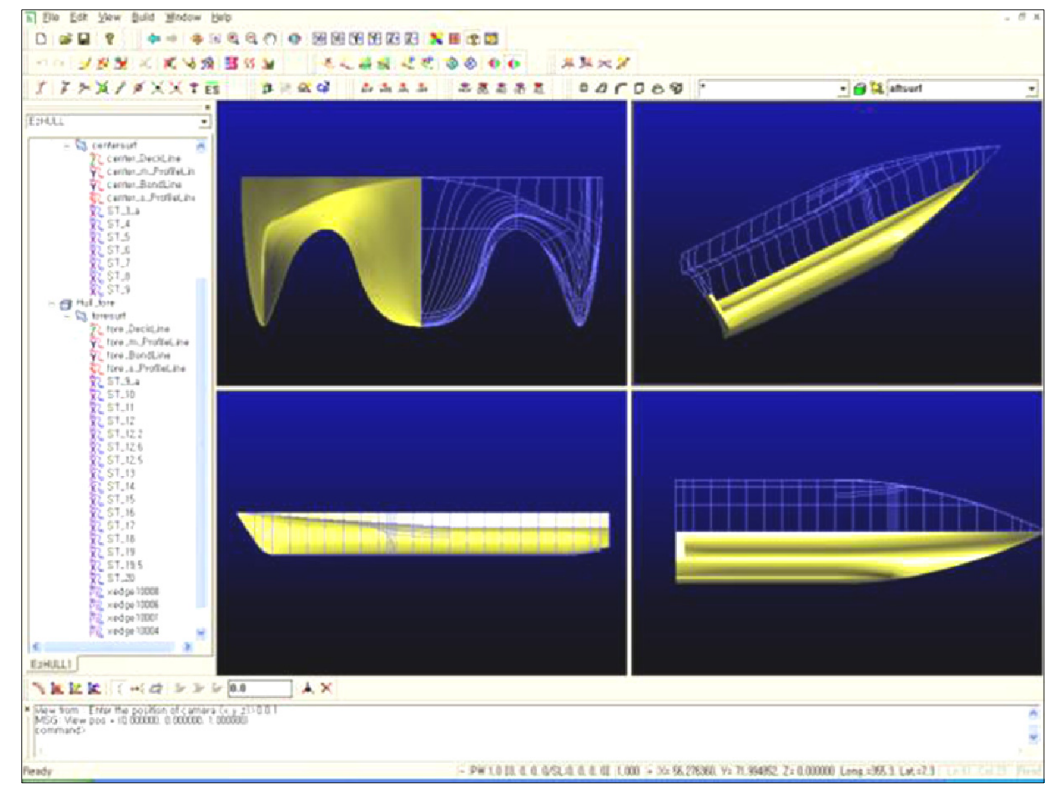

Fig. 1 Designing the hull form using "EzHull". 
- Second, students design the compartment of the model ship using "EzCOMPART" (see Fig. 2). In this procedure, the stability of the ship and the capacity of each compartment are checked.

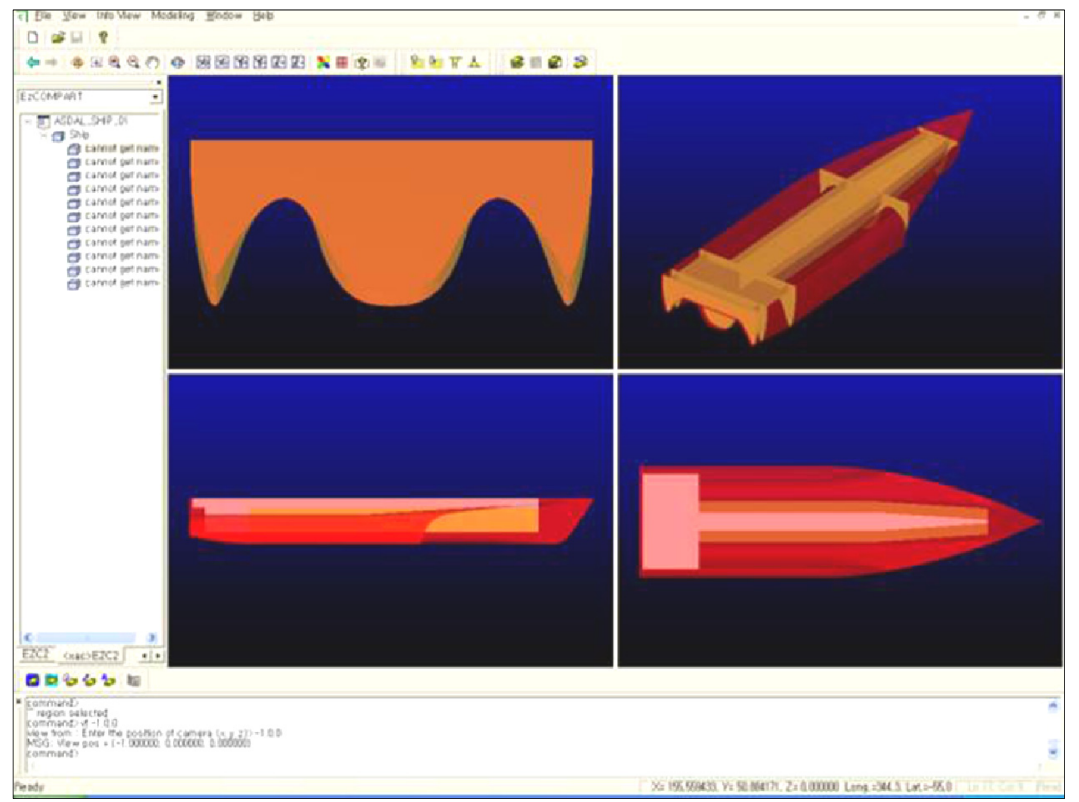

Fig. 2 Designing the compartment using "EzCOMPART".

- Third, students design the structural members of the model ship using "EzSTRUCT" (see Fig. 3). In this procedure, the strength of the model ship is checked.

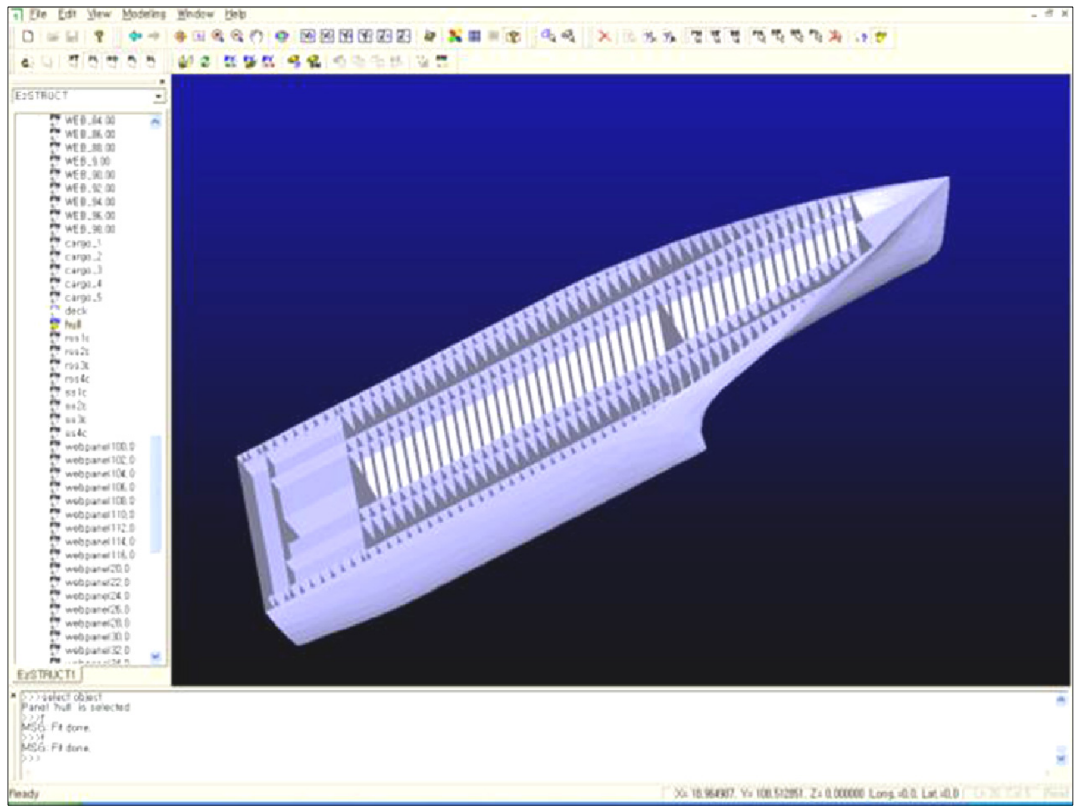

Fig. 3 Structural design using “EzSTRUCT”.

\section{Constructing a model ship}

Students construct a model ship based on the theory explained in Chapter 1. Each year, various subjects for the term projects are suggested in this lecture, and the subjects are listed in Appendix B. In this section, the procedure of constructing the model ship is presented using an example of the term projects. 
- Students design, cut, and assemble the structural members of the model ship. Figs. 4 and 5 show the structural members of a model ship and the assembly process.
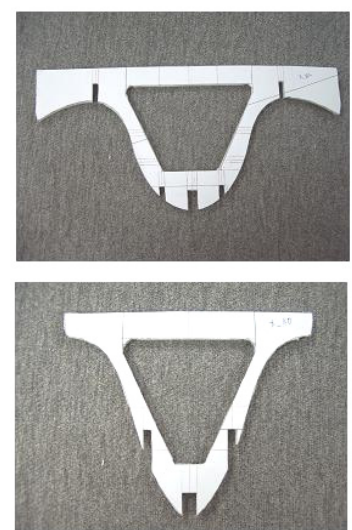

Fig. 4 The structural members of a model ship.
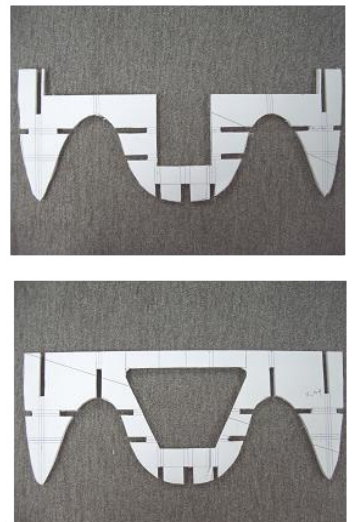

- Then, the students attach the shell plates of the model ship to the frames (see Figs. 6 and 7).

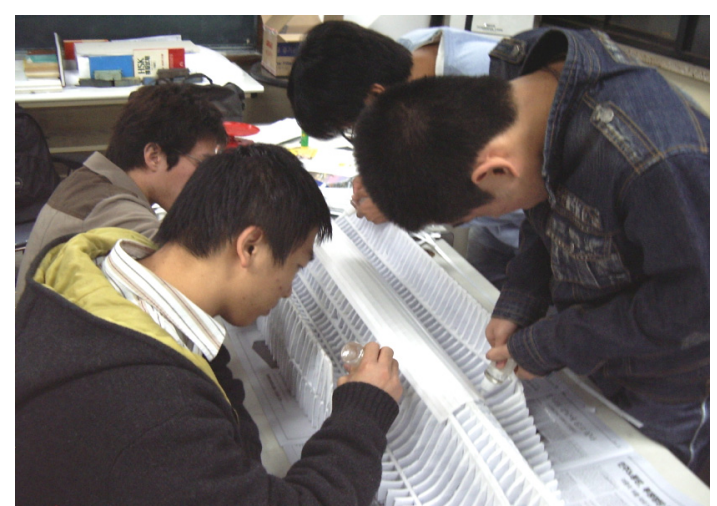

Fig. 6 Attaching the shell plates to the frames of a model ship.

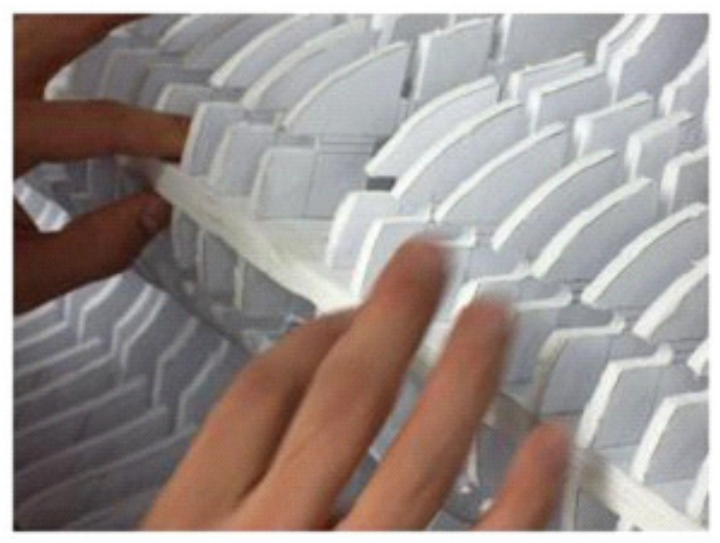

Fig. 5 Assembly of the structural members.

- Finally, students paint the model ship to make it waterproof and refine the hull form. After constructing the model ship, students examine the performance of their model ship using a trial run in a towing tank $(110 \mathrm{~m}$ in length, $8 \mathrm{~m}$ in width, $3.5 \mathrm{~m}$ in depth). The towing tank is the equipment of the department of Naval Architecture and Ocean Engineering of Seoul National University in Korea. Fig. 8 shows the trial run of a model ship.

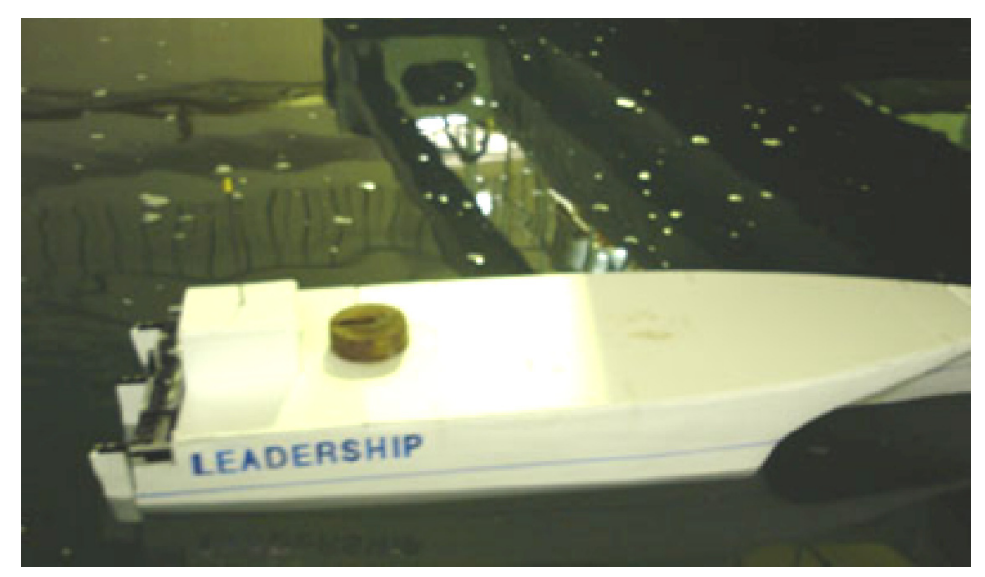

Fig. 8 Trial run of a model ship. 


\section{Contest to evaluate model ship}

The contest evaluates the model ship according to the following criteria.

- Speed: how long it takes to go to the specified location.

- Maneuverability: how long it takes to go to the specified location and return to the departure point.

To encourage students' interest in naval architecture, there are several awards in the contest such as best speed, best maneuverability, and best creative design. Students are also graded according to their model ship's performance in the contest.

\section{CAPSTONE DESIGN COURSE: INNOVATIVE SHIP DESIGN (ISD)}

The goal of this capstone design course is to (1) develop students' ship designing skills, (2) develop students' ability to solve engineering problems using the knowledge gained from their previous lectures, and (3) acquire teamwork and communication skills with other people in a group.

\section{Course overview}

The course introduces students to the following basic concepts of ship designing.
$\circ$ Weights of ship
$\circ$ Buoyancy
○ Ship stability
$\circ$ Powering
$\circ$ Hull form design
$\circ$ General arrangement
$\circ$ Hull structure
$\circ$ Outfitting
$\circ$ Economics

A team of 6-8 students complete a term project based on the given owner's requirements regarding the following tasks:
$\circ$ Determination of principal dimensions of ship
o Estimation of cargo hold volume
$\circ$ Prediction of speed and power
o Selection of main engine
$\circ$ General arrangement design
o Structural design of the midship section

$\circ$ Estimation of weight

○ Calculation of freeboard

o Determination of propeller principal dimensions

o Design of hull form by hull form variation method

○ Naval architectural calculation such as volume hydrostatics, trim \& stability, and longitudinal strength

To help students complete the tasks, the following procedure is used.

(1) Find applied problems.

(2) Construct mathematical models.

(3) Find a solving scheme (algorithm).

(4) Develop software.

(5) Write reports and make presentations.

For example, (1) if students need to determine ship's main dimensions, (2) they will construct a mathematical model using physical, economic, and regulatory constraints. To determine the optimal dimensions, they will set up the objective function. (3) They will then find the solving scheme (4) and will develop the optimization software using the technical knowledge acquired in their sophomore or junior classes. (5) After that, students will report and present the results of the term projects, including the procedure for completing the tasks.

\section{Capstone design projects}

Several types of ships or ship automation systems are suggested as subjects for the term projects. Fig. 9 shows the configuration of this course and examples of the subjects for the term projects. The subjects for the term projects are revised annually in accordance with the needs of the shipbuilding industry. 


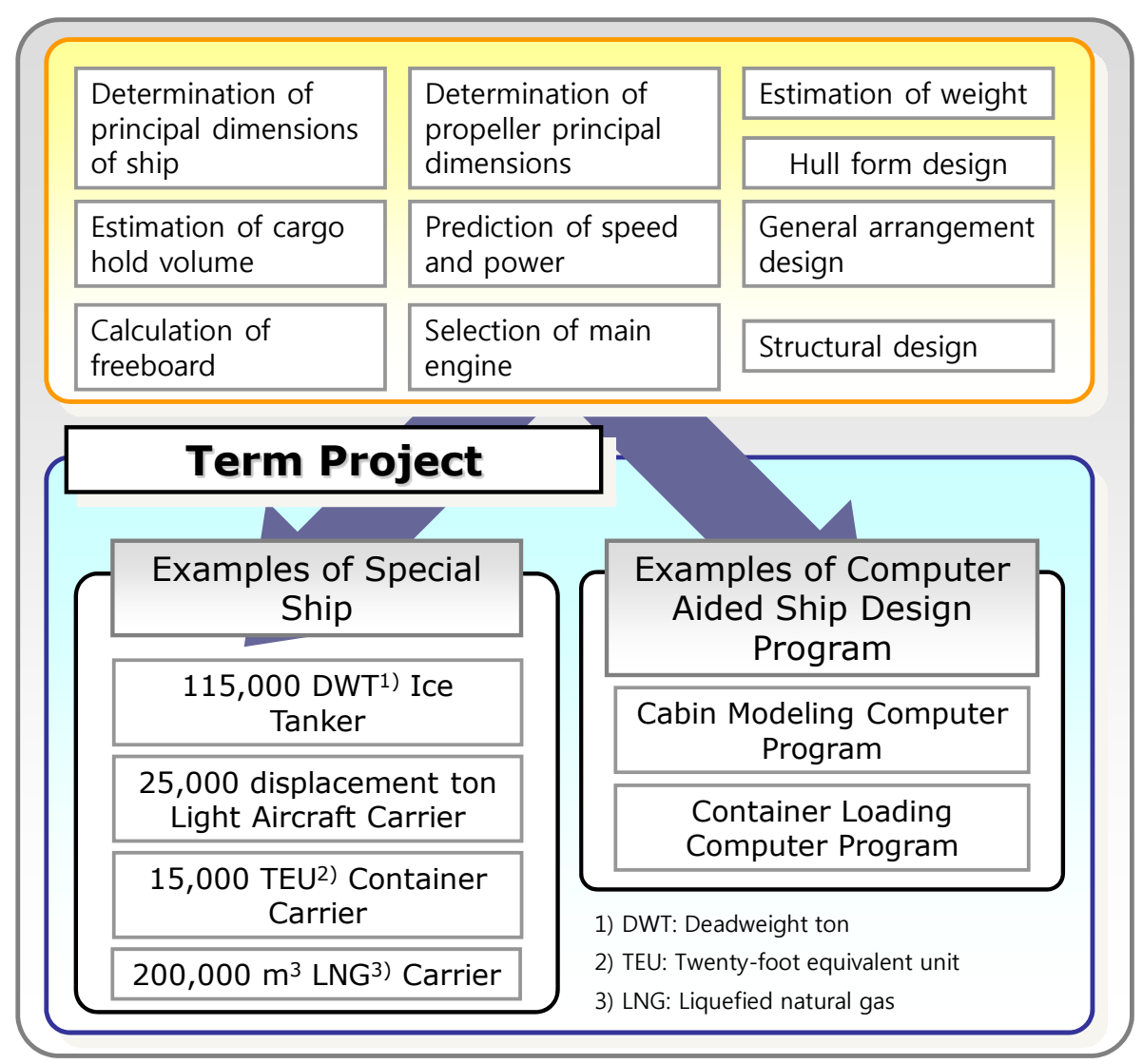

Fig. 9 Configuration of the "Innovative Ship Design" course.

Students select subjects for the term project and use their technical knowledge to complete it. Moreover, this lecture guides students in the development and use of their own software (see Figs. 12 and 13). Through the software development process, students learn exactly where the technical knowledge is applied and how the software is developed.

An example of the term project, the basic design process of the "25,000 displacement ton light aircraft carrier" is shown in the following figures (Figs. 10-17) and Table 1. Figs. 12-14 show the uses of the software developed by the students for completing the tasks. All the subjects of the term projects, provided in this lecture, are listed in Appendix A.

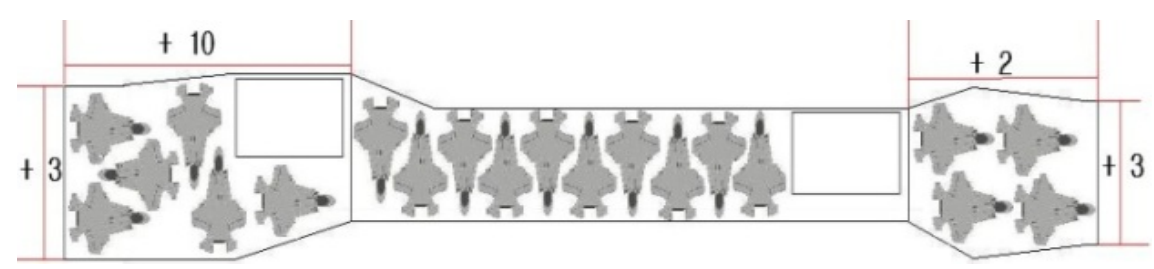

Fig. 10 Hanger design of the light aircraft carrier.

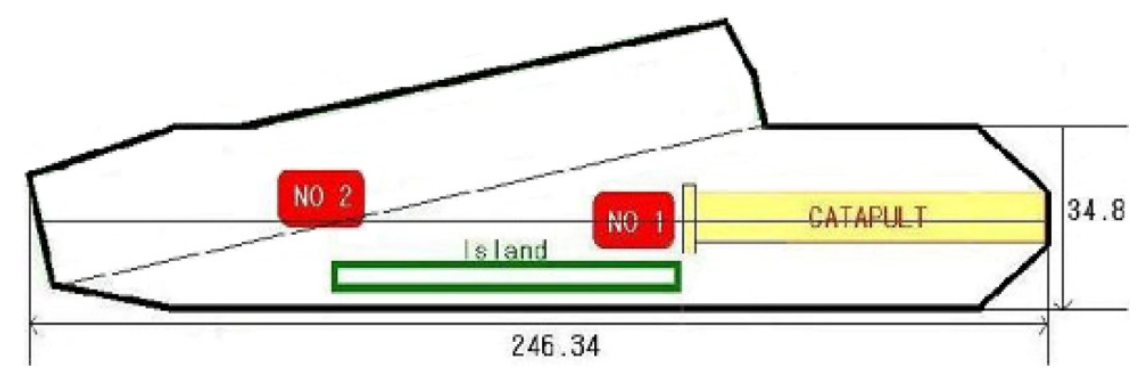

Fig. 11 Deck design of the light aircraft carrier. 


\begin{tabular}{|c|c|c|c|c|c|c|c|c|}
\hline \multicolumn{9}{|c|}{ Result Summary } \\
\hline DRAFT M & DISPL M & DISPL SW & DISPL FW & LCF & LCB & VCB & TPC & $\mathrm{MTC} / 100$ \\
\hline $\begin{array}{l}5.0 \\
5.2\end{array}$ & $\begin{array}{l}16121 \\
16959\end{array}$ & $\begin{array}{l}16524 \\
17383\end{array}$ & $\begin{array}{l}16121 \\
16959\end{array}$ & $\begin{array}{l}-4.087 \\
-4.604\end{array}$ & $\begin{array}{l}0.413 \\
0.178\end{array}$ & $\begin{array}{l}2.769 \\
2.884 \\
3.300\end{array}$ & $\begin{array}{l}42.6 \\
43.3\end{array}$ & $\begin{array}{r}4.3 \\
4.5\end{array}$ \\
\hline $\begin{array}{l}5.4 \\
5.6\end{array}$ & $\begin{array}{l}17811 \\
18674\end{array}$ & $\begin{array}{l}18256 \\
19141\end{array}$ & $\begin{array}{l}17811 \\
18674\end{array}$ & $\begin{array}{l}-5.094 \\
-5.441\end{array}$ & $\begin{array}{l}-0,063 \\
-0.304\end{array}$ & $\begin{array}{l}3.000 \\
3.115\end{array}$ & $\begin{array}{l}43.9 \\
44.5\end{array}$ & $\begin{array}{l}4.7 \\
4.8\end{array}$ \\
\hline 5.8 & $\begin{array}{l}19548 \\
20432\end{array}$ & 20037 & $\begin{array}{l}19548 \\
20432\end{array}$ & $\begin{array}{l}-5,708 \\
-5,023\end{array}$ & -0.540 & $\begin{array}{l}3.231 \\
3.345\end{array}$ & 45.1 & 5.0 \\
\hline 6.2 & 21326 & 21859 & 21326 & -6.085 & -0.988 & 3.462 & 46.0 & 5.2 \\
\hline $\begin{array}{l}6,4 \\
6.4\end{array}$ & $\begin{array}{l}22228 \\
22139\end{array}$ & $\begin{array}{l}227784 \\
23718\end{array}$ & $\begin{array}{lll}222228 \\
22139\end{array}$ & $\begin{array}{l}-6.222 \\
-6,329\end{array}$ & $\begin{array}{l}-1.198 \\
-1.398\end{array}$ & $\begin{array}{l}3.577 \\
3.692 \\
-1202\end{array}$ & 年6,5 & $\begin{array}{l}5.3 \\
54\end{array}$ \\
\hline 6.8 & 24059 & 24661 & 24059 & $-6,421$ & -1.589 & 3.807 & 47.3 & 5.5 \\
\hline 70 & 24967 & 25611 & 24567 & $=6.484$ & $\begin{array}{l}-1.169 \\
-1.940\end{array}$ & $\frac{3.922}{4.922}$ & 47.7 & 5.6 \\
\hline $\begin{array}{l}7.2 \\
7.4\end{array}$ & 26865 & $\begin{array}{l}265501 \\
27537\end{array}$ & 26865 & $\begin{array}{l}-6,588 \\
-6.582\end{array}$ & $\begin{array}{l}-1,1940 \\
-2,103\end{array}$ & $\begin{array}{l}4.560 \\
4.151\end{array}$ & 48,5 & $\begin{array}{l}5.7 \\
5.8\end{array}$ \\
\hline 7.6 & $\begin{array}{l}27816 \\
28773\end{array}$ & $\begin{array}{l}28511 \\
29493\end{array}$ & $\begin{array}{l}27816 \\
28773\end{array}$ & $\begin{array}{l}-6.611 \\
-6.637\end{array}$ & $\begin{array}{l}-2.256 \\
-2402\end{array}$ & $\begin{array}{l}4.266 \\
4.380\end{array}$ & 48.9 & 5.9 \\
\hline 8.0 & 29738 & 30482 & 29738 & $\begin{array}{l}-0.037 \\
-6.657\end{array}$ & $\begin{array}{l}-2,402 \\
-2.539\end{array}$ & $\begin{array}{l}4.4940 \\
4.950\end{array}$ & 49.6 & 6.1 \\
\hline 8.4 & 31689 & 32482 & 31689 & $\begin{array}{l}-6,6,2 \\
-6.677\end{array}$ & $\begin{array}{l}-2,600 \\
-2.794\end{array}$ & $\begin{array}{l}4.708 \\
4.722\end{array}$ & 50.4 & $\begin{array}{l}0.2 \\
6.3\end{array}$ \\
\hline 8.6 & $\begin{array}{l}32675 \\
33640\end{array}$ & $\begin{array}{l}334922 \\
34481\end{array}$ & $\begin{array}{l}32675 \\
33640\end{array}$ & $\begin{array}{l}-6.953 \\
-6.944\end{array}$ & $\begin{array}{l}-2.911 \\
-3027\end{array}$ & $\begin{array}{l}4.836 \\
4.947\end{array}$ & $\begin{array}{l}49.3 \\
496\end{array}$ & $\begin{array}{l}6.4 \\
6.4\end{array}$ \\
\hline 90 & 34611 & 35476 & 34611 & $\begin{array}{l}-6,944 \\
-6.933\end{array}$ & $\begin{array}{l}-3,017 \\
-3,136\end{array}$ & $\begin{array}{l}4.058 \\
5.74\end{array}$ & 49 & $\begin{array}{l}6.4 \\
6.5\end{array}$ \\
\hline 9.2 & 35589 & 36479 & 35589 & & 2 & 5.169 & 50.3 & 6.6 \\
\hline
\end{tabular}

Fig. 12 Hydrostatics calculation using the software developed by students.

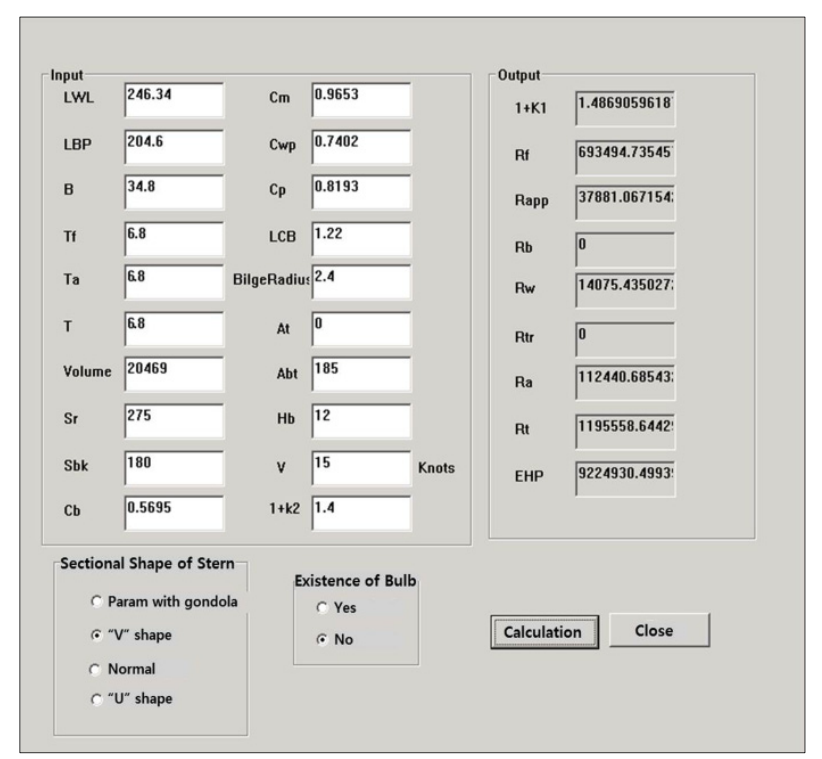

Fig. 13 Resistance estimation using the software developed by students.

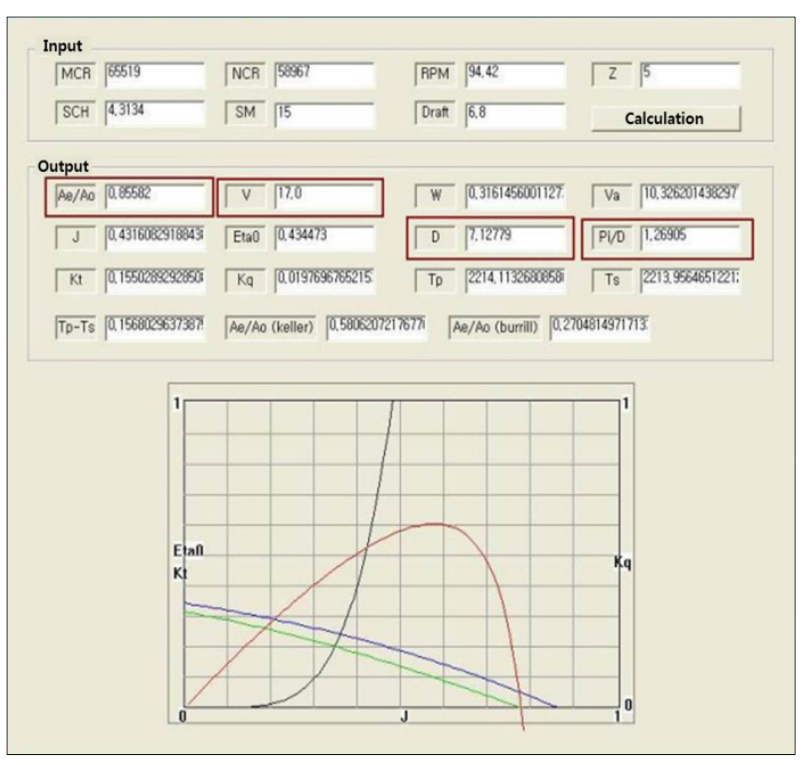

Fig. 14 Determination of the main dimensions of the propeller using the software developed by students.

Table 1 Main dimensions of the light aircraft carrier.

\begin{tabular}{|c|c|}
\hline Main dimensions & 246.34 \\
\hline Length over all $(m)$ & 34.8 \\
\hline Breadth (flight deck) $(m)$ & 21.45 \\
\hline Depth $(m)$ & 6.8 \\
\hline Design draft $(m)$ & 17,450 \\
\hline Lightweight $($ ton $)$ & 28 \\
\hline Maximum speed $(k n o t s)$ & 134,400 \\
\hline Engine power $($ NMCR) $(h p)$ (NMCR: Nominal Maximum Continuous Rating) & 0.5695 \\
\hline Block coefficient $(C b)$ & $(m)$ \\
\hline
\end{tabular}



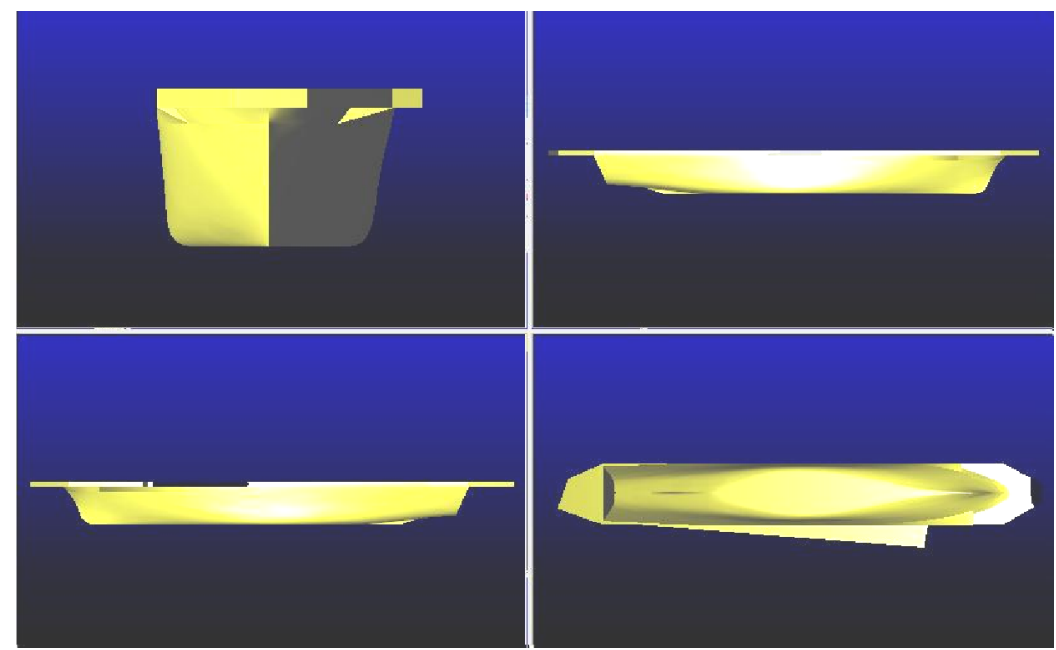

Fig. 15 Design of light aircraft carrier's hull form using "EzHULL".

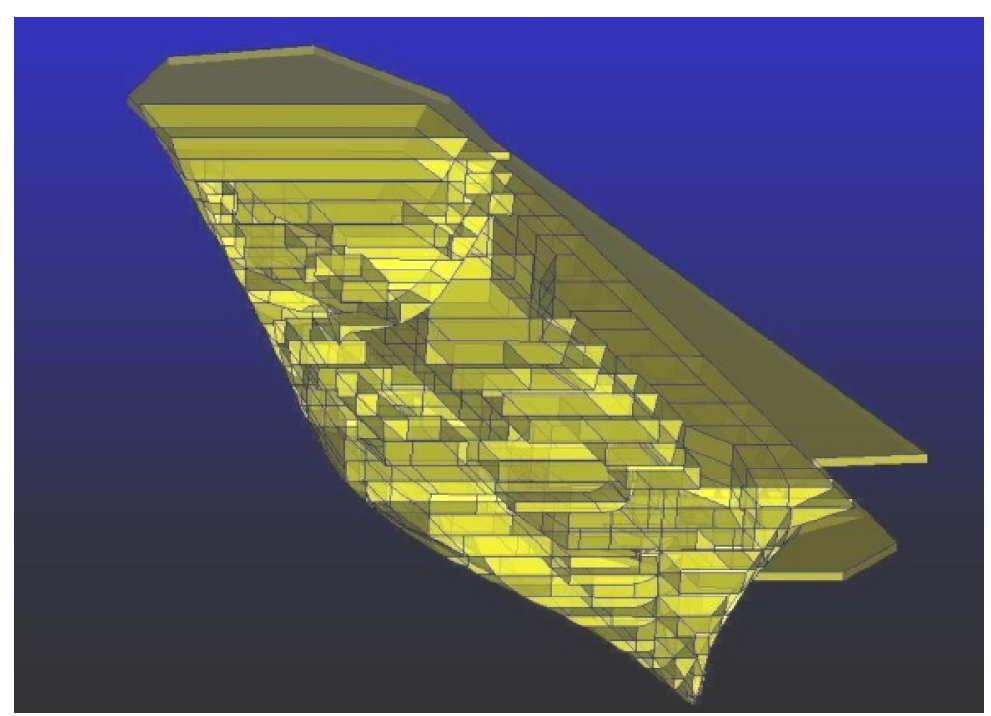

Fig. 16 Design of light aircraft carrier's compartments using “EzCOMPART”.

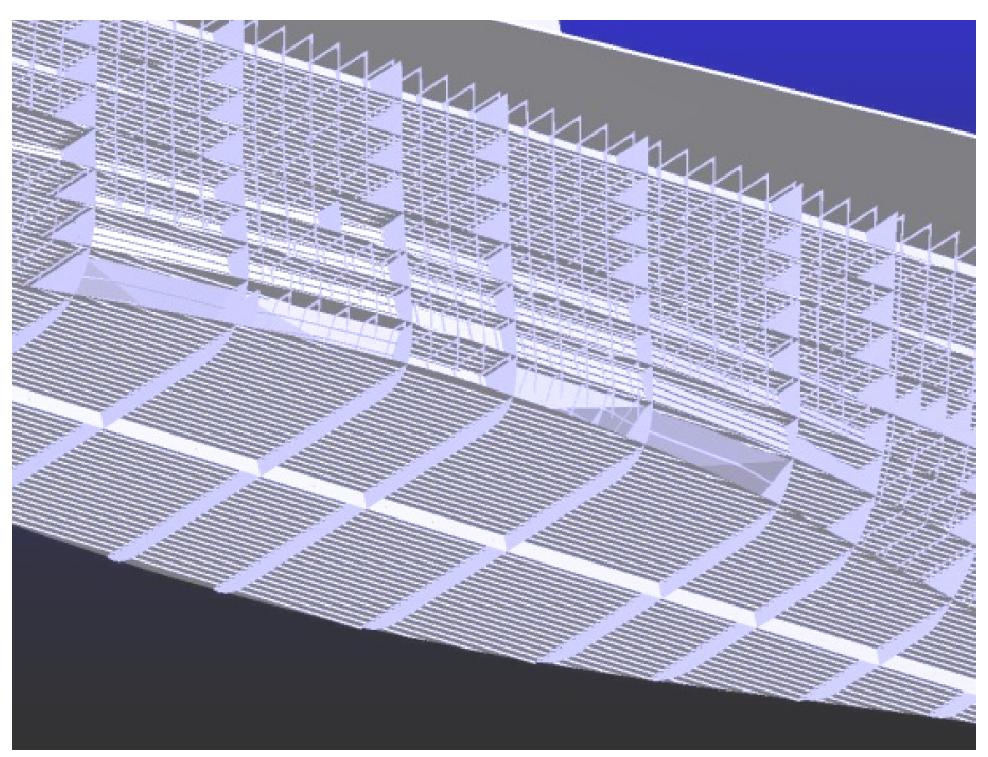

Fig. 17 Structural design of the light aircraft carrier using "EzSTRUCT". 


\section{Evaluation using a ship design contest}

To give students an opportunity to have their achievements assessed, this course encourages them to compete in the ship design contest organized by the Society of Naval Architects of Korea. Students who join the contest usually manifest more interest in ship design and achieve higher grades than other students.

In the ship design contest, students always received one of top 3 prizes. The results of the contests are listed in Appendix A. For the contest, teams from ISD prepared for 6 weeks, and the teams consisted of 6-8 students. The other teams prepared for 54 weeks, and consisted of 10-20 students. This demonstrates how the ISD course is intensive and effective for improving students' design skills.

\section{CONCLUSIONS AND FUTURE WORK}

This paper presented the curricula and results of two courses based on collaborative and project-based learning. These two lectures were established to enhance undergraduates' design ability. During the course, students learned the applications of the technical knowledge that they had gained in their sophomore or junior classes. Software for the course was developed by students and also partially provided by the author's laboratory. Students participated in a model ship contest and a ship designing contest, which motivated their interest in naval architecture. The results of the ship design contest show the lectures were effecttive and intensive for enhancing students' design ability. In the future, the subjects for the projects in the two lectures will be updated to reflect the latest issues in the naval architecture industry.

\section{ACKNOWLEDGEMENTS}

This work was partially supported by:

1) The Industrial Strategic Technology Development Program (10035331, Simulation-based Manufacturing Technology for Ships and Offshore Plants) funded by the Ministry of Knowledge Economy (MKE, Korea).

2) EzGRAPH Co., Ltd.

3) The Research Institute of Marine System Engineering, Seoul National University.

\section{REFERENCES}

Gokhale, A.A., 1995. Collaborative learning enhances critical thinking, Journal of Technology Education, [online] Available at: http://scholar.lib.vt.edu/ejournals/JTE/v7n1/gokhale.jte-v7n1.html?ref=Sawos.Org [Accessed 10 April 2013].

Goodsell, A.S., Maher, M.R. and Tinto, V., 1992. Collaborative learning: A sourcebook for higher education. National Center on Postsecondary Teaching, Learning, and Assessment, University Park, PA.

Hanai, T., Arita, I., Sawada, S., Ushijima, K., Yoshimoto, K. and Makizono, K., 2007. Bi-directional practical education through industry-university cooperation. IPSJ Journal, 48(2), pp.832-845.

Ito, A., Watanabe, Y., Kurematsu, A., Murakami, H., Yuyama, I., Miyamichi, J., Hasegawa, H., Hososhima, M., Tsukikawa, A. and Fujii, M., 2007. Issues on business-academia collaboration in the development of educational course; For the design, development and implementation of practical cell phone software. IPSJ Journal, 48(2), pp.846-857.

Johnson, R.T. and Johnson, D.W., 1986. Action research: Cooperative learning in the science classroom. Science and Children, 24(2), pp.31-32.

Lee, K.Y., 2006. Planning procedure of naval architecture \& ocean engineering, Fall 2006. Seoul National University, Retrieved from http://ocw.snu.ac.kr/.

Lee, K.Y., 2009. Innovative ship design, Spring 2009. Lecture note, Seoul National University, Retrieved from http://ocw. snu.ac.kr/.

Lee, K.Y., Cha, J.H. and Ku, N.K., 2011. Ship stability. 7th ed. Advanced Ship Design Automation Laboratory, Seoul National University (in Korean).

Matsuzawa, Y. and Ohiwa, H., 2007. A result of trial education for software engineers through university-industry collaboration and project-based learning. IPSJ Journal, 48(8), pp.2767-2780.

Terenzini, P.T., Cabrera, A.F., Colbeck, C.L., Parente, J.M. and Bjorklund, S.A., 2001. Collaborative Learning vs. Lecture/ Discussion: Students' Reported Learning Gains. Journal of Engineering Education, 90(1), pp.123-130.

Totten, S., Sills, T., Digby, A. and Russ, P., 1991. Cooperative learning: A guide to research. New York: Garland. 
APPENDIX A

\begin{tabular}{|c|c|c|c|c|}
\hline \multirow{2}{*}{ Year } & \multirow{2}{*}{ Design objective } & \multicolumn{2}{|c|}{$\begin{array}{l}\text { Participation in } \\
\text { ship design } \\
\text { contest }\end{array}$} & \multirow{2}{*}{$\begin{array}{c}\text { Award } \\
\text { list }\end{array}$} \\
\hline & & $\begin{array}{l}\text { Specified } \\
\text { theme }\end{array}$ & $\begin{array}{l}\text { Free } \\
\text { theme }\end{array}$ & \\
\hline \multirow{11}{*}{2002} & $\begin{array}{l}\text { 15,000 Displacement Ton Light } \\
\text { Aircraft Carrier }\end{array}$ & & $\mathrm{O}$ & $2^{\text {nd }}$ Prize \\
\hline & $80,000 \mathrm{GT}^{1)}$ Cruise Ship & & $\mathrm{O}$ & $2^{\text {nd }}$ Prize \\
\hline & $\begin{array}{l}\text { 30,000 ton SWATH }{ }^{2)} \text { Cruise } \\
\text { Ship }\end{array}$ & & $\mathrm{O}$ & $3^{\text {rd }}$ Prize \\
\hline & $145,000 \mathrm{~m}^{3} \mathrm{LNG}^{3)}$ Carrier & & & \\
\hline & 214 Class Submarine & & & \\
\hline & $\begin{array}{l}320,000 \text { DWT }^{4)} \text { Twin Skeg } \\
\text { VLCC }^{5)}\end{array}$ & & & \\
\hline & $\begin{array}{l}182,000 \text { DWT Double-side Skin } \\
\text { Bulk Carrier }\end{array}$ & & & \\
\hline & 8-Seater $\mathrm{WIG}^{6)}$ & & & \\
\hline & 9,000 TEU ${ }^{7)}$ Container Carrier & & & \\
\hline & $240,000 m^{3}$ LNG-FPSO $^{8)}$ & & & \\
\hline & 450,000 DWT ULCC ${ }^{9}$ & & & \\
\hline \multirow{11}{*}{2003} & $160,000 \mathrm{~m}^{3} \mathrm{LNG}$ Carrier & & & \\
\hline & $\begin{array}{l}40,000 \text { Displacement Ton } \\
\text { LHD }^{10)}\end{array}$ & & $\mathrm{O}$ & $2^{\text {nd }}$ Prize \\
\hline & $\begin{array}{l}\text { 2,500 Displacement Ton } \\
\text { Submarine }\end{array}$ & & & \\
\hline & $\begin{array}{l}225,000 \mathrm{~m}^{3} \text { LPG Condensate } \\
\mathrm{FSO}^{11)}\end{array}$ & & & \\
\hline & 6,000 GT Research Icebreaker & & & \\
\hline & 12,000 TEU Container & & & \\
\hline & $\begin{array}{l}\text { 100,000 Displacement Ton } \\
\text { Aircraft Carrier }\end{array}$ & & & \\
\hline & $\begin{array}{l}\text { 6,400 Unit Multipurpose Car } \\
\text { Carrier }\end{array}$ & & & \\
\hline & 3,400 GT Car Ferry & & & \\
\hline & 100,000 GT Cruise Ship & & & \\
\hline & 148,500 DWT Shuttle Tanker & & & \\
\hline \multirow{6}{*}{2004} & 115,000 DWT Ice Class Tanker & & & \\
\hline & $\begin{array}{l}\text { 25,000 Displacement Ton Light } \\
\text { Aircraft Carrier }\end{array}$ & & $\mathrm{O}$ & $2^{\text {nd }}$ Prize \\
\hline & 15,000 TEU Container Carrier & & & \\
\hline & $200,000 \mathrm{~m}^{3} \mathrm{LNG}$ Carrier & & $\mathrm{O}$ & $3^{\text {rd }}$ Prize \\
\hline & $\begin{array}{l}\text { Cabin Modeling Computer } \\
\text { Program }\end{array}$ & & $\mathrm{O}$ & \\
\hline & $\begin{array}{l}\text { Container Loading Computer } \\
\text { Program }\end{array}$ & & & \\
\hline
\end{tabular}

\begin{tabular}{|c|c|c|c|c|}
\hline \multirow{2}{*}{ Year } & \multirow{2}{*}{ Design objective } & \multicolumn{2}{|c|}{$\begin{array}{l}\text { Participation in } \\
\text { ship design } \\
\text { contest }\end{array}$} & \multirow{2}{*}{$\begin{array}{l}\text { Award } \\
\text { list }\end{array}$} \\
\hline & & $\begin{array}{l}\text { Specified } \\
\text { theme }\end{array}$ & $\begin{array}{l}\text { Free } \\
\text { theme }\end{array}$ & \\
\hline \multirow{6}{*}{2005} & $\begin{array}{l}210,000 \mathrm{~m}^{3} \text { Ice Class LNG } \\
\text { Carrier }\end{array}$ & & & \\
\hline & $\begin{array}{l}\text { 20,000 Displacement Ton } \\
\text { Nuclear-powered Ice Breaker }\end{array}$ & & & \\
\hline & 112,500 GT Cruise Ship & & $\mathrm{O}$ & $1^{\text {st }}$ Prize \\
\hline & 33,000 DWT Drillship & & & \\
\hline & $\begin{array}{l}\text { 8,300 Displacement Ton Nuclear- } \\
\text { powered Submarine }\end{array}$ & & & \\
\hline & $250,000 \mathrm{~m}^{3} \mathrm{LNG}$ Carrier & $\mathrm{O}$ & & $2^{\text {nd }}$ Prize \\
\hline \multirow{6}{*}{2006} & 4,100 TEU Container Carrier & $\mathrm{O}$ & & $2^{\text {nd }}$ Prize \\
\hline & $\begin{array}{l}\text { 18,600 Displacement Ton } \\
\text { Nuclear-Powered Ice Breaker }\end{array}$ & & $\mathrm{O}$ & $2^{\text {nd }}$ Prize \\
\hline & $\begin{array}{l}\text { 42,000 GT Ro-Ro }{ }^{12)} \text { Passenger } \\
\text { Ship }\end{array}$ & & $\mathrm{O}$ & $2^{\text {nd }}$ Prize \\
\hline & $180,000 \mathrm{~m}^{3} \mathrm{LNG}$ Carrier & & $\mathrm{O}$ & $2^{\text {nd }}$ Prize \\
\hline & $\begin{array}{l}\text { 3,000 Displacement Ton Nuclear- } \\
\text { powered Submarine }\end{array}$ & & $\mathrm{O}$ & $2^{\text {nd }}$ Prize \\
\hline & $145,000 \mathrm{~m}^{3}$ Ice Class LNG Carrier & & $\mathrm{O}$ & \\
\hline \multirow{8}{*}{2007} & $\begin{array}{l}\text { 180,000 DWT New Panamax } \\
\text { Class Bulk Carrier }\end{array}$ & $\mathrm{O}$ & & \\
\hline & $280,000 \mathrm{~m}^{3} \mathrm{LNG}_{\mathrm{FSRU}}{ }^{13)}$ & & $\mathrm{O}$ & $2^{\text {nd }}$ Prize \\
\hline & $210,000 \mathrm{~m}^{3} \mathrm{LNG} \mathrm{RV^{14 } )}$ & & $\mathrm{O}$ & $2^{\text {nd }}$ Prize \\
\hline & $110,000 \mathrm{~m}^{3} \mathrm{PNG}^{15)}$ Carrier & & & \\
\hline & $84,000 \mathrm{~m}^{3} \mathrm{CNG}^{16)}$ Carrier & & & \\
\hline & $200,000 \mathrm{~m}^{3} \mathrm{LNG}$ FPSO & & & \\
\hline & $\begin{array}{l}170,000 \mathrm{~m}^{3} \text { Methane Hydrate } \\
\text { FPSO }\end{array}$ & & & \\
\hline & $110,000 \mathrm{~m}^{3} \mathrm{LPG}^{17)}$ Carrier & & $\mathrm{O}$ & \\
\hline \multirow{3}{*}{2008} & 4,200 TEU Container Carrier & & & \\
\hline & 320,000 DWT VLCC & $\mathrm{O}$ & & \\
\hline & $\begin{array}{l}\text { 3,000 GT Education and Training } \\
\text { Ship of Korea Coast Guard }\end{array}$ & & $\mathrm{O}$ & $2^{\text {nd }}$ Prize \\
\hline \multirow{3}{*}{2009} & 4,800 TEU Container Carrier & & & \\
\hline & $\begin{array}{l}87,400 \text { DWT Tanker for New } \\
\text { Panamax Canal }\end{array}$ & $\mathrm{O}$ & & \\
\hline & $\begin{array}{l}210,000 \mathrm{~m}^{3} \mathrm{LNG} \text { carrier with Fuel } \\
\text { Cell Hybrid-powered Engine }\end{array}$ & & $\mathrm{O}$ & $2^{\text {nd }}$ Prize \\
\hline \multirow[b]{2}{*}{2010} & 7,500 TEU Container Carrier & & & \\
\hline & $\begin{array}{l}\text { Korea Coast Guardship with Re- } \\
\text { ducing the Fuel for Environment }\end{array}$ & & $\mathrm{O}$ & \\
\hline
\end{tabular}

\footnotetext{
${ }^{1)}$ GT: Gross Tonnage

${ }^{2)}$ SWATH: Small Waterplane Area Twin Hull

${ }^{3)}$ LNG: Liqufied Natural Gas

4) DWT: Deadweight Ton

${ }^{5)}$ VLCC: Very Large Crude oil Carrier

${ }^{6)}$ WIG: Wing in ground

7) TEU: Twenty-foot Equivalent Unit

${ }^{8)}$ FPSO: Floating Production Storage Offloading

${ }^{9)}$ ULCC: Ultra Large Crude oil Carrier
}

${ }^{10)}$ LHD: Landing Helicopter, Dock

11) FSO: Floating Storage and Offloading

${ }^{12)}$ Ro-Ro: Roll-on Roll-Off

${ }^{13)}$ FSRU: Floating Storage and Regasification Unit

${ }^{14)} \mathrm{RV}$ : Regasification Vessel

${ }^{15)}$ PNG: Pressurized Natural Gas

16) CNG: Compressed Natural Gas

${ }^{17)}$ LPG: Liquefied Petroleum Gas 


\section{APPENDIX B}

\begin{tabular}{|c|c|c|}
\hline \multirow{2}{*}{ Year } & \multicolumn{2}{|r|}{ Design objective } \\
\hline & Type of ship & Function / Control \\
\hline 2004 & Free selection & $\begin{array}{l}\text { - Propulsion system } \\
\text { - Maneuvering system }\end{array}$ \\
\hline 2005 & Crane ship & $\begin{array}{l}\text { - Propulsion system } \\
\text { - Maneuvering system } \\
\text { - Cargo loading/Unloading system by crane }\end{array}$ \\
\hline 2006 & Cargo ship & $\begin{array}{l}\text { - Propulsion system } \\
\text { - Maneuvering system } \\
\text { - Distance-keeping system by infrared sensor }\end{array}$ \\
\hline 2007 & Free selection & - Position control system for a ship by PID control \\
\hline 2008 & Floating crane & $\begin{array}{l}\text { - Position control system for a ship by PID control } \\
\text { - Position sensing system for a ship and for a cargo by gyroscope }\end{array}$ \\
\hline
\end{tabular}

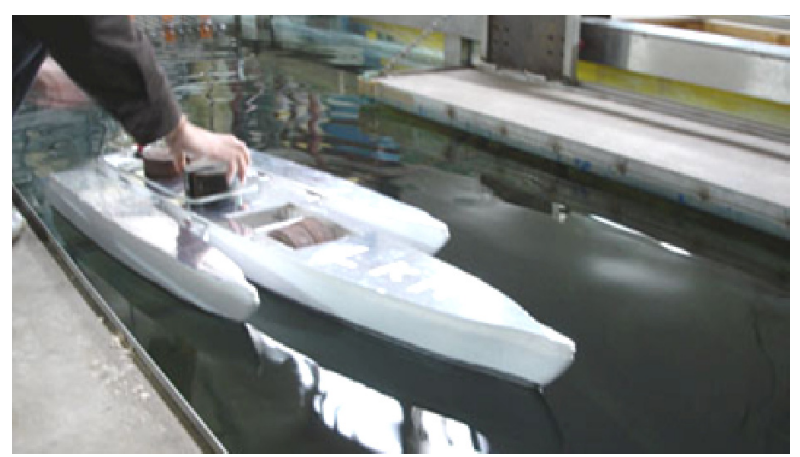

$1^{\text {st }}$ prize, Trimaran in model ship contest 2004.

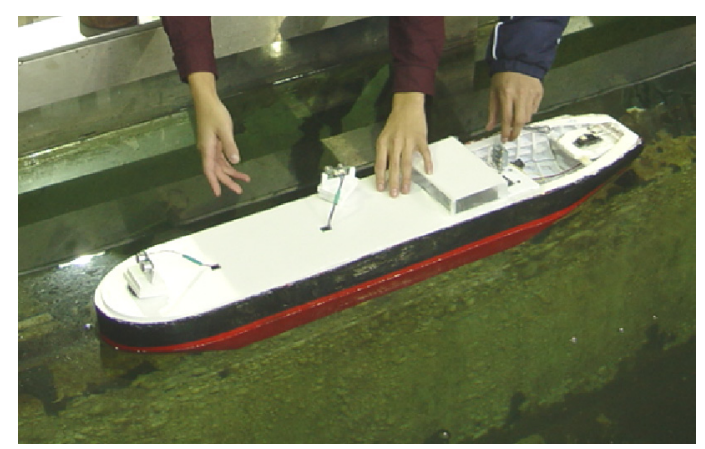

$1^{\text {st }}$ prize, Crane ship in model ship contest 2006.

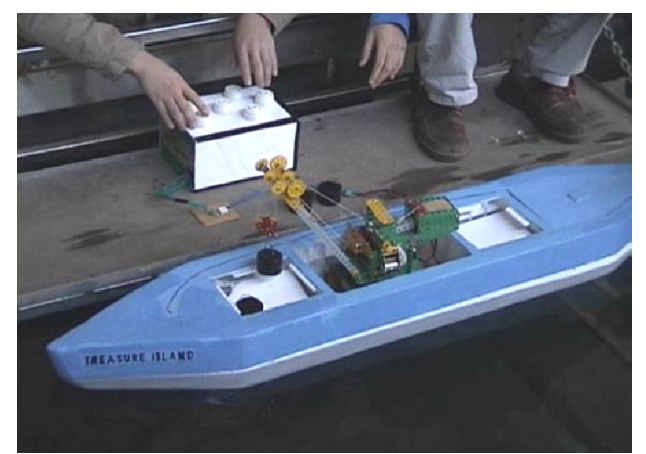

$1^{\text {st }}$ Prize, Crane ship in model ship contest 2005.

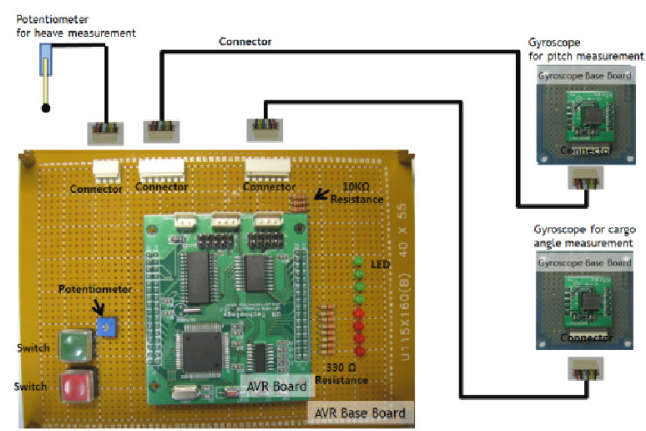

$1^{\text {st }}$ prize, Position control system in model ship contest 2007.

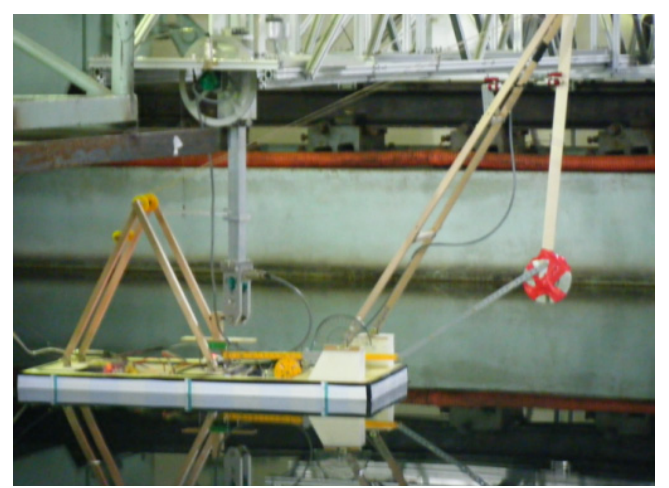

$1^{\text {st }}$ prize, Floating crane in model ship contest 2008. 